\title{
Chapter 6: Bioethics and Biosecurity Education in China: Rise of a Scientific Superpower
}

\section{MICHAEL BARR AND JOY YUEYUE ZHANG}

This chapter explores ethics, education and the life sciences in China. It is based on work conducted by the authors in two separate but complimentary projects. ${ }^{1}$ Barr's observations derive from interviews and discussions in Beijing, Shanghai and Guangzhou with life scientists and policymakers in infectious-disease hospitals, university-research labs, the Chinese Academy of Sciences, and the Ministry of Health. Zhang's study focused on China's governance of stem-cell research and involved interviews with scientists, ethicists and policymakers at more than 25 sites across China. Below, we set the context by describing the role of science in China's quest to become a leading power and then consider the place of bioethics within China. We follow this with a discussion of three key areas that have impacted our work and describe some of the lessons we have taken from our experience for future research on bioethics education and biosecurity in China. We conclude with a set of suggestions about what can be done to further biosecurity awareness within China.

For the sake of clarity, we should note our use of terms. By 'biosecurity' we refer to the protection and control of pathogens and toxins to prevent their deliberate theft, misuse, or diversion for the purposes of biological warfare or terrorism. According to our use of the word, this includes researchers' personal knowledge, choices and behaviour, as well as society's collective responsibility to safeguard a population from the dangers of pathogenic microbes. We use the term in contrast to 'biosafety', which we see as laboratory procedures and policies aimed at reducing accidental exposures. Contained within the term 'biosecurity' is the dual-use dilemma, which refers to the possibility that the same scientific research, products, or facilities which are meant for social good could also have an unintended result of threatening a population, either

\footnotetext{
1 We gratefully acknowledge the support of our funders for this research. The Alfred P. Sloan Foundation in the US and the UK Department of Universities, Innovation and Skills funded Barr's work. Zhang held a Wellcome Trust Biomedical Ethics Studentship Award for her study.
} 
inadvertently or through a deliberate act of bioviolence. Finally, by 'awarenessraising', we accept the Biological and Toxin Weapons Convention's (BTWC) definition of 'improving dialogue and communication' between all 'relevant stakeholders, including policymakers, the scientific community, industry, academia, media and the public in general' ${ }^{2}$ However, our own work (and thus our focus in this chapter) concentrates mainly on educational and informational initiatives aimed at the scientific and academic community in China, mainly life scientists and ethicists.

\section{Rise of a Scientific Superpower}

The rise of China constitutes one of the greatest stories of the early twenty-first century. China's impact extends across nearly every sphere - from international finance and trade, to culture and soft power, to global security and weapons proliferation. In the West, when observers discuss Chinese power, there is often a fear palpable beneath the surface: will this country of 1.3 billion people seek to play by the rules of the game (that is, be 'status-quo') or will it become a revisionist state, intent on re-writing the norms of the international system in line with its own perceived interests $?^{3}$ And on this question, perhaps no sector raises more concern than the nexus between security and technology.

Since the 1990s science has been a cornerstone of Chinese development. Expenditure on research and development rose from 0.6 per cent of GDP in 1996 to 1.4 per cent in $2006 .{ }^{4}$ During this time, the Chinese government set up numerous policies to attract talented life-science researchers, including 'the one thousand talents' campaign which seeks to lure foreign-trained Chinese scientists back home with the contractual promise of high salaries and state-ofthe-art facilities.

Beijing's ambitions to become a world leader in science and technology should not be underestimated. President Hu Jintao noted in 2006 that China's general goal was to 'visibly increase the country's indigenous innovation capacity, visibly increase the capacity of science and technology to promote economic and social development and guarantee national security, visibly increase the overall research strength of basic sciences and frontier technologies, strive for scientific and technological achievements of major world implications' ${ }^{5}$

2 Biological and Toxin Weapons Convention 2007, Report of the 2007 Meeting of States Parties, BWC/ MSP/2007/5, para. 21.

3 Johnston, A. 2003, 'Is China a status quo power?' International Security, vol. 27, pp. 5-56.

4 Chen, Z. 2008, 'Biomedical science and technology in China', The Lancet, vol. 372, pp. 1441-3.

5 Zhu, Z. and Xu, G. 2008, 'Basic research: Its impact on China's future', Technology in Society, vol. 30, p. 296. 
These comments were soon supported by very real and quantifiable goals:

By the year 2020, the ratio of gross expenditure on research and development will rise to over 2.5 per cent; the contribution rate of scientific and technological advance to economic growth will rise to over 60 per cent; the dependence on foreign technologies will drop to less than 30 per cent; and the annual granting of invention patents to Chinese nationals and the international citation of scientific papers will rank among the world's top five. ${ }^{6}$

Approximately 20 per cent of this total investment goes to the life sciences, an area in which China has made considerable progress. ${ }^{7}$ As early as 2000 , Beijingbased genomic centres were estimated to have had more sequencing capacity than France and Germany combined ${ }^{8}$ Whilst the most visible success of Chinese life scientists was the 2002 decoding of the rice genome, China has attracted the attention and interest of both European and US audiences across a number of fields.

China's great leap forward in science and technology begs the question whether similar gains have been made in attempts to socially regulate emerging technologies. The answer, as in most countries, is mixed. Some still portray China as a 'Wild East', a place where scientific progress need not be hampered by ethical reservations or public unease. ${ }^{9}$ With doubts over standards in regulatory enforcement and of transparency, combined with large amounts of funding for scientists who are under pressure to generate results, and a culture that - on the surface at least - seems to downplay the importance of individual rights, critics contend that biomedical research in China remains ethically problematic. ${ }^{10}$ However, what such accounts miss is the sizable body of regulation pertaining to biological research, including guidelines on biomedical studies involving human subjects, specific advice on clinical drug trials and embryonic stemcell research, as well as provisions for good clinical and laboratory practice. Crucially, informed-consent requirements, provisions for review by ethics committees, and legal sanctions feature prominently in many regulations. ${ }^{11}$ of course, germane to successful regulation is education and awareness-raising.

6 Ibid.

7 Chen, Z., Wang, H. G., Wen, H. J. and Wang, Y. 2007, 'Life sciences and biotechnology in China', Philosophical Transactions of The Royal Society, vol. 362, pp. 947-57.

8 Schneider, L. 2003, Biology and Revolution in Twentieth-Century China, Lanham: Rowman \& Littlefield.

9 Wilsdon, J. and Keeley, J. 2007, China: The next science superpower? The Atlas of Ideas: Mapping the new geography of science, London: DEMOS, available at: www.demos.co.uk

10 Hennig, W. 2006, 'Bioethics in China', EMBO Reports, vol. 7, pp. 850-4.

11 Medical Research Council 2009, China-UK Research Ethics (CURE) Committee Report, London: Medical Research Council. 


\section{Nascent but Growing: Bioethics Education in China}

Medical ethics teaching in China began in the 1980s. However, early courses were limited to abstract (and solely Western) theories and principles of general ethics. In order to help boost student interest in ethics, Chinese lecturers, with assistance from The China Medical Board in New York and the Chinese Society of Medical Ethics (formed in 1988), sought to reform teaching to incorporate ideas and cases relevant to Chinese culture. ${ }^{12}$

A number of factors have since contributed to the steady growth of ethics teaching. ${ }^{13}$ First, the jump in numbers of science students in China has meant that universities have had to expand their provision of ethics courses. Postgraduate programmes in biomedical ethics have been established in a number of key institutions, with the first Master's degree being offered at Tianjin Medical University in 2000. A second reason is the manifold problems faced by China's public-healthcare system. The benefits of China's rapid economic growth have been uneven, badly affecting healthcare services. For instance, it is estimated that only 10 per cent of the rural poor have adequate facilities for sanitation, whilst less than 30 per cent have a reliable source of drinking water. ${ }^{14}$ Exacerbating these problems is the plight of China's migrant population: 140 million people are excluded from public medical insurance as they move between cities and the provinces in search of improved opportunities. ${ }^{15}$ In this context, it is not surprising that China has sought to develop greater capacity to study, debate, and solve such issues that put a strain on the healthcare and biomedical establishment.

\section{The 'Software' Problem: Ethics Education as a Biosecurity Strategy}

The connection between public health, public policy, and ethics education is evident when examining biosecurity in China. ${ }^{16}$ Chinese leaders were deeply embarrassed by the severe acute respiratory syndrome (SARS) outbreak in 2003, which some estimate cost the country US\$10 billion in lost tourism revenues

12 Yali, C. 2003, 'Comparison of medical ethics education between China and the United States', in Song, S. Y., Koo, Y. M. and Macer, D. (eds), Bioethics in Asia in the 21st Century, New Zealand: Eubios Ethics Institute; Doering, O. 2003, 'Teaching medical ethics in China. Cultural, social and ethical issues', in Song, Koo, and Macer (eds), op. cit.

13 Li, E. C. 2008, 'Bioethics in China', Bioethics, vol. 22, pp. 448-54.

14 Tang, S., Meng, Q., Chen, L., Bekedam, H., Evans, T. and Whitehead, M. 2008, 'Tackling the challenges to health equity in China', The Lancet, vol. 372, pp. 1493-501.

15 Hu, S., Tang, S., Liu, Y., Zhao, Y., Escobar, M. L. and de Ferranti, D. 2008, 'Reform of how health care is paid for in China: Challenges and Opportunities', The Lancet, vol. 372, pp. 1846-53.

16 Barr, M. 2009, 'China's role as a biosecurity actor', in Rappert, B. and Gould, C. (eds), Biosecurity: Its Origins, Transformations and Practice, Basingstoke: Palgrave Macmillan. 
alone. ${ }^{17}$ Whilst fears that the epidemic would spread to rural areas were not realised, SARS nonetheless highlighted the inequalities of China's healthcare system. Its impact on China can hardly be understated. One microbiologist and biosecurity expert at the Chinese Academy of Medical Sciences explained that SARS was as important to China as the 11 September terrorist attacks were to the US in terms of their political, economic and psychological consequences.

Whilst China responded to the crisis with a range of new regulations (including revision of its 1989 Law on the Prevention and Treatment of Infectious Diseases), the need for greater education and training was brought rudely to attention again in 2004. A batch of the SARS virus at the National Institute of Virology in Beijing, mistakenly thought to have been inactivated, was moved from a BSL-3 storage container to a non-regulated lab where medical students were working on diarrheal diseases. The breach of security subsequently resulted in eight infections and one death, as well as the temporary closure of the Institute and quarantine of over 700 individuals suspected of coming into contact with the virus. The accident had clearly been the result of human negligence. One microbiologist at Fudan University refers to this as a 'software' problem - meaning that whilst much attention has been paid to the 'hardware' (the building of hi-tech labs, autoclaves, cabinets, locks, doors, and so on), the human element of biosecurity has been neglected. That is, the training, behaviour, management skills, expert knowledge, and duties of care needed to operate high-level laboratories safely have not kept pace with the introduction of new facilities.

The 'software' problem includes much more than lab safety. Yet statements by the Chinese Delegation to the BTWC Meeting of Experts show that their focus is almost entirely on safety, not the wider issue of dual use. According to their declaration, biosecurity 'education and awareness raising' refer solely to 'laboratory safety management and technical training, biosafety licensing, preparedness for health emergency and response and veterinary biosafety'. ${ }^{18}$ These efforts are obviously important and are to be supported. However, like other countries with growing biotechnology sectors, China's adoption of educational measures and codes of conduct aimed at addressing a broader agenda of oversight of the life sciences and how biological research might be exploited for illegitimate purposes, remains uneven. A small number of top universities and scientific associations, including the Chinese Academy of Sciences (CAS) have sought to establish an internal code of ethics that aims to promote scientific ethics, as well as the integrity and moral character of staff. CAS has also set up

17 Wen, H. 2004, 'The Short Term Impact of SARS on the Economy', Asian Economic Papers, vol. 3, pp. 57-61.

18 Chinese Delegation to the Biological and Toxin Weapons Convention Meeting of Experts 2008a, Statement made on Biosafety \& Biosecurity Capacity Building; Chinese Delegation to the Biological Weapons Convention Meeting of Experts 2008b, Poster on China's Practice on Biosafety and Biosecurity. 
a special commission for scientific integrity to promote transparency, autonomy and accountability of research. These types of codes are to be encouraged and broadened to specifically promote dual-use awareness. Yet it must be noted that CAS is essentially the scientific arm of the government, supported by the State Council itself, and considered to be the most prestigious scientific institution in the country. Whilst bodies like CAS may set a useful example, the real challenge lies in reaching provincial and district-level labs, especially outside the main urban settings, where it is harder to monitor activities.

It is important to reiterate that the amount of attention paid to dual-use issues varies according to the site. In 2002, China's main legislative body, the State Council, passed two sets of regulations regarding dual-use equipment and technologies. ${ }^{19}$ The directives contained measures to strengthen export controls to prevent the diversion of dual-use biological agents, related equipment, and technologies that could be used in weapons production. It also included an export-licensing system and provisions for the criminal prosecution of domestically based violators. Significantly, the export-control list covered within the regulations provided an extensive list of pathogens and toxins, thus putting China in accord with control lists of the Australia Group (to which it still does not formally belong). Whilst we have no reason to doubt the enforcement of these regulations, on the wider issues of personal responsibility, we found that most Chinese life scientists we interviewed were not particularly concerned about the dual-use implications of their work and did not regard bioterrorism or bioweapons as substantial threats. The reasons for this varied, but, as in the West, many scientists in China tend to view scientific progress as inevitable and generally think that pressures to publish and present findings mean that research will, one way or another, be conducted and find its way into the public domain..$^{20}$ Our findings were confirmed by the views of participants at China's first ever, international meeting dedicated to the dual-use dilemma. Organised by CAS in 2008, with the support of the Inter Academy Panel and the Organisation for Economic Co-operation and Development (OECD), delegates to the workshop expressed concern over dual-use issues but also agreed that different stakeholders tended to view the concerns differently. Compared to security specialists, scientists in general were seen as being unaware of the potential dual-use nature of their research.

The remainder of this chapter will address several themes from our experience of researching and promoting bioethics in China and propose a series of practical steps that could help promote biosecurity education.

19 State Council of China 2002a, Regulation of the People's Republic of China on Export Control of Dual-Use Biological Agents and Related Equipment and Technologies; State Council of China 2002b, Dual-Use Biological Agents and Related Equipment and Technologies Export Control List.

20 For more on scientists' levels of awareness, see Rappert, B. 2007, Biotechnology, Security, and the Search for Limits, Basingstoke: Palgrave Macmillan. 


\section{Lessons Along the Science/Society/Security Interface}

\section{Ethicisation: How an Issue Becomes an Ethical Problem}

In the West, social scientists working in the area of science and security studies are alert to how key actors transform certain issues into security concerns. This process is referred to as 'securitisation' and involves studying 'who securitises, on what issues, for whom, why, with what results, and under what conditions' ${ }^{21}$ Similarly, during our work in China we came to see that it was necessary to heed attention to the way in which an issue becomes a source of bioethical (and biosecurity) concern. Zhang has coined the term 'ethicisation' to refer to a process of raising awareness. ${ }^{22}$ Its function is to map out the social, legal, political and financial concerns that scientists should take into consideration. Like securitisation, ethicisation embraces no specific moral objectives. It can, however, lead to a re-evaluation of existing judgments.

In this context it is important to remember that life-science research cannot be conducted without international collaboration. Chinese scientists are not only heavily involved in joint projects with Western colleagues but participate in a multitude of exchange programmes and seek to publish their results in English-language journals. So, as transnational investment and communication become standard practices, 'ethical concerns' in need of regulation become 'infectious'. The necessity to facilitate cooperation has resulted in the request for increased compatibility of local frameworks with that of the potential partners. Consequently, bioethics is no longer a segmented social aspect rooted solely in a specific cultural milieu. The perception of research priorities is shaped as much by national factors as they are by debates in the global scientific and bioethical communities. And this, of course, has knock-on effects for how ethics is taught.

One example may help to shed light on this process. On a visit to a regional headquarters of the China Hematopoietic Stem Cell Data Bank, the director told Zhang how visiting Western stem-cell banks expanded her awareness of ethical issues. In the original planning of their cell bank's office space, people walk in and are first welcomed by a whole wall of glass-panelled covered shelves, with hundreds of neatly arranged binders holding donor data. The director felt this was a nice way to store data and incentivise employees. She explained as follows:

It wasn't considered an ethical issue. It was an aesthetic issue. Plus, it is difficult to persuade people to donate blood stem cell in China [because

21 Buzan, B., Waever, O. and Wilde, J. 1998, Security: A New Framework for Analysis, Boulder: Lynne Rienner Publishers.

22 Zhang, J. Y. 2010, 'China's Regulation of Stem Cell Research in the Context of Cosmopolitanisation', Doctoral Thesis, Department of Sociology, London School of Economics and Political Science. 
traditionally blood is considered an essence of vitality]. I thought a whole wall display of the data books behind the glass panel is a magnificent display of our hard work. It would boost morale... But during my visit to stem-cell donor data banks in the US, I didn't see any data-collection shelves throughout my whole trip. I asked them why. They told me data books are stored in limited-access rooms to protect patients' privacy. Then I realised: Ah! The display of shelves is an ethical issue.

So whilst in the US, arrangement of data books implies protection of patients' confidentiality and professional accountability, in China, it was originally perceived as an 'aesthetic issue'. The director's trip to the US made her think from an alternative perspective: office-space arrangement not only matters to staff members, but also has wider implications to stem-cell donors, patients and medical practitioners. One consequence of the exposure to foreign practice, however, is that it unexpectedly extends the range of ethical-related issues that Chinese stem-cell banks acknowledge.

There is no textbook answer to the complete set of ethical issues that scientists or administrators should be aware of. Instead, what stakeholders have on hand is a growing list of items they need to consider. This list increases as stakeholders' communicative circles expand. The internationalisation of science rewrites the criteria for good practice through the process of ethicisation, or the institutionalisation of a societal issue. Such institutionalisation leads to the encouragement and requirement that scientists and other stakeholders (policymakers, educators, patients) consider a specific concern whilst reflecting on their practice and outcome.

A similar process can be seen in relation to biosafety. Whilst biosafety was considered a personal lab issue prior to the SARS outbreak in 2003 and accidental exposure in 2004, it is now a matter of national - indeed international security. This has prompted China to pay far more attention to biosafety and pour considerable resources into ensuring ethical conduct within labs. For instance, during a visit to an infectious-disease hospital in Shanghai, Barr was struck by the status and level of respect paid to two young staff members who had recently returned from a World Health Organisation (WHO)-sponsored training programme on biosafety. Although they were quite junior staff, the director of the hospital and another senior colleague indicated that the two employees were in high demand and crucial to the successful running of the site since work in their newly built BSL-4 lab could not proceed without their assistance. Thus, an issue that was previously of local or even personal importance has become institutionalised as a wider ethical and security matter.

One lesson we draw from this is that it is vital to be attuned to how the global or local interface may influence, in any given national context, what type of issues 
are on the educational agenda (or, crucially, not). In China, where science is a key component of its national development and political and economic strategy, it is imperative that staff are aware of foreign practices and concerns as to what constitutes an ethical or security issue. It is vital for Chinese scientists to be seen to be doing the right thing. This means that a balance must be achieved between advocating an educational agenda, based on international norms, that is 'right' and 'ethical' and, as we shall discuss below, not overselling or pushing foreign solutions onto Chinese partners.

\section{Scientists as Ethics Decision-Makers}

After an issue makes its way onto the agenda, a key question then becomes who has the social power and authority to negotiate it? Earlier we discussed the nascent but growing role of bioethicists in China. In line with this, Zhang has found that it is often scientists who are the key players in ethical policy matters but that ethicists have been slowly making progress in getting their voices heard. One respondent put it this way:

We are entitled to the right of speech. We can express our opinions towards the policy, but that is all. For most major policy, it is still made according to what the officials envisaged. In other words, we can criticise the policy, both through public media and through official administrative channels, but they [government policymakers] don't really listen to all the experts' advice... Of course they listen to the 'hard-core experts' advice, especially for stem-cell research, MOST [Ministry of Science and Technology] won't listen to us [ethicists], it only turns its ear to real scientists.

Another senior bioethicist spoke of her efforts to travel across China in order to raise awareness of the non-scientists' ability to help adjudicate bio problems.

My role was to 'make a little noise'... Really, what is essential in promoting bioethics in China is, as my colleagues and I call it, 'to make a little noise' ... In the past few years, my colleagues and I have been invited by institutions across China to give lectures, give speeches, provide training or write for newspapers. Whenever the topic touches on bioregulation, we tell people our perspectives on biomedical research. In fact, we are creating general alertness. We try to raise others' attention, make people think about these issues, and see whether we should [have some form of administrative action].

Whilst in many Western countries, bioethics as a discipline, has been professionalised and is part of the institutional framework for debating ethical issues, in China bioethics has shown a degree of separation between its social 
function and professional merit. On reflecting how Chinese ethicists could improve their social functions, one ethicist at the Chinese Academy of Social Sciences (CASS) said:

Bioethicists should not be living in a vacuum. I think most of the ethicists [in China] are familiar with Western thinking. In what is considered ethical and what is not, [Chinese] ethicists don't really follow the Chinese convention. As a profession, we are heavily influenced by American and European academia. Especially after our [stem cell] guideline was issued, questions arise from both inside and outside China. We [ethicists] must change our approach towards addressing ethical concerns [in China], and start thinking about these questions. Therefore, we really should examine our own tradition and how it is different from the West... I'm not quite sure how ethical consulting agencies work in the US, how they function, but I do feel that they have a say in policymaking. What is more, they always incorporate a wide range of concerns, religion, science, ethics, law... Their report includes all kinds of opinion from all kinds of social groups. In comparison, when bioethicists are contributing to policymaking in China, I feel we can only propose some personal opinion on this issue. We cannot mobilize a wide range of social groups [to participate]. Public participation is minor and professionals at different levels also have little chance of being involved.

Similarly, during trips to Fudan University in Shanghai and Sun Yat-sen University in Guangzhou, Barr discovered that most, if not all, biosecurity classes and textbooks were being designed and taught without any input from ethicists or social scientists. The only survey that seems to have been conducted into biosecurity educational curriculum in China was organised by a leading microbiologist at Fudan. We discuss some of the possible reasons for the lack of input from social scientists and ethicists below. Furthermore, from our vantage point, the dominant role of scientists as ethics deciders in China implies several key lessons.

Firstly, it was important to know the social and academic status of the actors we wished to reach and what was and was not within their abilities to deliver. In our case, we learned that involving bioethicists was a useful way of getting insights into the larger context of Chinese humanities and social-sciences education but that crucially, if we wanted to make real progress in getting biosecurity modules into the classroom, we needed to collaborate extensively with life scientists. Secondly, when dealing with scientists, we went out of our way to gain their trust by showing that we knew what we were talking about and could relate in some sense to their priorities as leading life scientists. Thirdly, we found it tricky to share a common language with those not well versed in the humanities 
or social sciences (a problem obviously not unique to China). This meant that we had to be more creative, for example, in discussing why seemingly abstract ethical theories may be appropriate to scientists engaged in dual-use research.

\section{The Status of the Social Sciences}

Some of the challenges described above can be traced to the general status of the social sciences (and by association, humanities) in China. We have identified three broad areas in which the history and role of social scientists and ethicists in China may impact efforts to promote bioethical and biosecurity education.

Firstly, there is the question of self-censorship within Chinese academia. CASS was established in 1977 to advise the government and Communist Party and acted as an in-house think-tank for various political factions. It was set up to serve the reforms of Deng Xiaoping and essentially to separate the social from the natural sciences. After the involvement of many CASS staff in the 4 June 1989 demonstrations, the Academy was reformed - or one might say, 'rehabilitated'. Whilst there are ample outlets for CASS academics to publish, many think twice before exposing their work to political criticism. Li Tieying, former President of CASS is rather clear on this point: 'At CASS, behaviour that damages the Chinese Communist Party (CCP), socialist China, the world of social science, or CASS itself is absolutely intolerable'. If, as is sometimes the case, writers do not know where the border lies between safety and punishment, then understandably there is a tendency to 'retreat into a conspiracy of silence', with a reluctance to take on issues which may be seen as sensitive - such as biosecurity. ${ }^{23}$

Secondly, twentieth-century social science in China maintained not only a uniform tendency towards empirical research but also a belief in its technocratic potential to transform society. ${ }^{24}$ Despite the effects of the Cultural Revolution (1966-76), when academic inquiry ground to a halt, the social sciences in China today tend to hold similar beliefs. It is only a slight generalisation to say that in China academics often view their work as service to the nation. This is perhaps a difficult concept for Western academics to appreciate. It is impossible in China today to speak against patriotism. The term youhuan yishi (忧患意识) is relevant here as it refers to worries about the future of China, common amongst intellectuals. ${ }^{25}$ Youhuan yishi constitutes a moral concern with improving the nation's wellbeing. It denotes rhetoric of worrying about the nation that remains integral to Chinese intellectual discourse, whether it be interpreted as simply

\footnotetext{
23 Sleeboom-Faulkner, M. 2007, 'Regulating intellectual life in China: The case of the Chinese Academy of Social Sciences', The China Quarterly, vol. 189, p. 99.

24 Chiang, Y. 2001, Social Engineering and the Social Sciences in China, 1919--1949, Cambridge: Cambridge University Press.

25 Davies, G. 2007, Worrying about China: The language of Chinese critical inquiry, Cambridge: Harvard University Press.
} 
improving the socio-economic plight of the Chinese, or recovering a genuine way of 'being Chinese' and China's international status as a great scientific and cultural power. ${ }^{26}$ One consequence of this is that amongst Chinese intellectuals (that is, some of the key academics, whose support is necessary to help further biosecurity awareness), there is ambivalence towards foreign or imported ideas.

Thirdly, one consequence of the state of social sciences in China is that there are sometimes no comparable fields to the ones we tend to take for granted in the West. For example, there is no real equivalent in China to Science and Technology Studies. Thus, some of the academic terms, theories, concerns, and norms that we use do not necessarily carry over. In the West, for instance, many working along the science/society/security interface subscribe to the notion of the co-production of knowledge - that is, to the belief that the natural and social order are produced together and the ways in which we know and represent the world are inseparable from the ways we chose to live in it. According to this view, science does not mirror reality. Rather, it both embeds and is embedded in social practices, norms, identities, and institutions. ${ }^{27}$ Such a school of thought may seem out of place in China. Gloria Davies who writes that 'Unlike its Western counterpart, Chinese academic discourse remains a quest for certainty, a quest envisaged in terms of the acquisition of better, more rational, and theoretically refined knowledge', captures this difference nicely. ${ }^{28}$

All of this may seem far removed from bioethics and biosecurity education. But there are several lessons we take from these points. In one recent case, Barr sought funding to undertake a project on biosecurity in China. The funder stipulated that Chinese partners must come from CASS. However, it emerged that there was no one at the Academy who had relevant expertise for the application. ${ }^{29}$ Although we cannot know for certain, it seems possible that one reason this area is avoided is its political sensitivity; that is, its proximately to questions of national security. During an earlier experience in China, Barr was told by a senior ethicist that conducting ethics research into infectious disease would be very sensitive and that it would be necessary to proceed cautiously since some people may not be willing to talk about the topic given its connection to matters of security and government censorship.

It is interesting here to consider the official oath taken by medical students. In addition to the usual duties of moral discipline and medical skill, it includes mention of love of country and people:

\footnotetext{
26 Link, P. 1998, Evening chats in Beijing, New York: W.W. Norton and Company, Inc.

27 Jasanoff, S. 2004, States of knowledge: The co-production of science and the social order, London: Routledge.

28 Davies 2007, op. cit.

29 In a way this may not be surprising since, as discussed above, biosecurity is new to the policy agenda. Yet despite being 'new', it has not stopped some life scientists from getting involved with biosecurity work.
} 
I will devote my life to the cause of medicine. I love my country. I will be loyal to the people. I will adhere to strict medical ethics. I will respect my teachers and observe discipline. I will study diligently and constantly in order to perfect my medical skills and to develop myself in all possible aspects - morally, intellectually and physically. ${ }^{30}$

The point here is that, in China at least, there is sometimes a strong (techno) nationalist backdrop to many issues, especially ones such as the science/society/ security interface. This is important, in part, since the government is by far the largest funder for scientists. Seen this way, promoting a patriotic discourse may serve several purposes. One key strategy the government has used to lure scientists back to China is to appeal to their sense of nationalism in helping to build a scientifically competitive superpower. This relates to a final point worth considering for foreign researchers wishing to collaborate with Chinese partners. It has to do with earning trust - or, to put it another way, avoiding suspicion. As we went about our separate studies, it was not uncommon for us to be asked whether or not we were journalists. This fear seemed to stem not so much from concerns over security but rather that we would do or print something to harm our respondent's (and China's) reputation. Some the most damaging stories about hospitals, doctors, and ethics violations have sprung from the media in China. As we conducted our work in the run up to the 2008 Olympics, we could not help but notice a worry over being embarrassed whilst the international spotlight shone on the Beijing Games. Of course, it is always the case that researchers must work in partnership with each other. Our point here is for foreign researchers working in China to be sensitive to the patriotic backdrop to Chinese science, an element that is often missing in Western academia.

\section{Conclusion: What Can Be Done?}

There are numerous ways to help promote biosecurity education in China. We conclude this chapter by suggesting three key interrelated contributions that researchers (Chinese and foreign) may make.

First, there is a need to improve data sharing and cross-lab communication in China. Our work has found that whilst scientists in China tend to talk about collaboration with other local sites, in fact, communication between labs is more limited than one might expect. ${ }^{31}$ The first step here is to help promote the type of workshop that CAS ran in 2008 on dual-use research (cited above).

30 People's Republic of China Ministry of Education 1991, Official Oath for Medical Students, Appendix 4 of Document No. 106.

31 Zhang, J. Y. 2010, 'The organization of scientists and its relation to scientific productivity: Perceptions of Chinese stem cell scientists', BioSocieties, vol. 5(2). 
The goal of such a meeting is not only for biosecurity-minded staff in China to exchange views with foreign experts. Whilst this is important, there is also a great need for researchers within China to share and learn from one another. China is in the unique position of having the second-largest economy in the world and yet in per-capita income terms, it ranks ninety-ninth. ${ }^{32}$ This shows just how uneven growth and development has been, which has knock-on effects for what different sites will consider to be the range of biosecurity issues and priorities it faces. Of course income gaps will also have significant effects on levels of resources and abilities to promote biosecurity awareness. Thus, it is crucial that scientists from China's leading centres are brought together with staff from less-resourced hospitals and labs. Only in this way can we ascertain across sites what is already being done, at what levels, and for which students and lab workers. This leads us to our second point, which is to use this data to help build biosecurity capacity in China.

Second, biosecurity-minded researchers ought to work towards establishing compulsory biosecurity classes for all life-science students. This could supplement scientific-morality courses that are already required of most students. It is sometimes mistakenly assumed that in China all change comes from the top down. Whilst government statements at the BTWC illustrate the political importance of biosecurity, our experience is that the fastest way to change is when leading institutions - such as CAS - make grass-roots initiatives that, once established, draw the attention and support of government ministries. The aim here is to work with interested staff at high-profile key sites to assess the possibilities and practical issues that must be overcome in establishing a required course (including instructors who are trained to deliver such a class). These moves can then be supported with biosecurity and dual-use teaching resources appropriate to the needs and context of the life sciences in China. This leads to our third point.

Third, in order to help facilitate mandatory courses, appropriate materials are needed. One way to do this would be to draw on the EMR, an open-access series of lectures to support life scientists and educators in learning about biosecurity and dual-use issues (see the chapter by Whitby and Dando). The aim here is to help interested social and life scientists in China design resources and methods suitable to their context (with, for example, particular emphasis on the security implications of infectious-disease research). This suggestion requires researchers working together, across sites, to develop and share texts and ideas for the effective delivery of biosecurity classes. It would not necessarily require starting from scratch, as part of the aims in our first suggestion would be to assess which

32 International Monetary Fund 2009, World Outlook Economic Database, Washington: International Monetary Fund. 
sites are using which materials and provide the chance for biosecurity educators to reflect with one another on the usefulness or otherwise of the books and examples they employ.

If adopted, these suggestions could have positive knock-on effects. One of the main regulatory challenges in China is not a lack of rules but rather, a lack of effective enforcement of the rules that already exist. Thus, our suggestions are practical steps that aim to help create a culture of responsibility, whereby enforcement mechanisms are strengthened through widespread awareness and education. 